\title{
KONSEP DZIKIR MENURUT AMIN SYUKUR DAN RELEVANSINYA DENGAN TUJUAN PENDIDIKAN ISLAM
}

\author{
Oleh: \\ Siti Yumnah \& Abdul Khakim \\ Sekolah Tinggi Agama Islam Pancawahana Bangil \\ sitiyumnah30@gmail.com \\ khakima919@gmail.com
}

\begin{abstract}
:
Recitation as act of worship, according to Amin Syukur is a form of worship of beings, especially humans to Allah with the awareness of remembering Him. Where when remembrance involves between taste and brain simultaneously it will have a very extraordinary effect. The foundation of remembrance of Amen Gratitude is 4: remembrance qauly, zikir qalbi, remembrance of spirit and remembrance fi'ly. There are also 4 benefits of dzikir mentioned by Amin Syukur: (a) establishing faith (b) growing positive moral energy (c) avoiding danger and (d) as mental therapy. The relevance of remembrance with the aim of Islamic education according to Amin Syukur has a very close relationship. Remembrance is a way to make a person become a good, noble human being and of course remember his creation in this world which can lead people to become insan kāmil. Because it integrates the vision of faith, science and humanity where its formation is built through the process of Islamic education.

Insan Kāmil without Islamic education will not be able to do the regeneration so that will result in the extinction of oneself (experiencing gaps even the disappearance of cadres who carried out the relay of the struggle of Insan Kāmil). On the contrary Islamic education without Insan Kāmil will not have a thing system that guarantees the birth of educational cadres who can take part in the future progress of life. The results of the research are expected can provide a reference for the education system so need attention for affective and psychomotor domains also.
\end{abstract}

Keyword: The Concept of Remembrance, Amin Syukur, The Purpose of Islamic Education

\section{A. Pendahuluan}

Zaman modern yang sarat dengan persaingan hidup, munculnya sikap individualistis, egoistis dan materialistis mendatangkan dampak berupa kegelisahan, kecemasan, stres dan depresi. Berangkat dari 
kenyataan masyarakat modern yang telah mencapai puncak kenikmatan materi justru berbalik dari apa yang diharapkan, yakni mereka dihinggapi rasa cemas, sehingga tanpa disadari integritas kemanusiannya tereduksi dan terperangkap pada sistem rasionalitas teknologi yang sangat tidak manusiawi. Akibatnya masyarakat modern tidak mempunyai pegangan hidup yang mapan, lebih dari muncul dan brutal serta menyimpang.

Banyak sekali fenomena yang dihadapi oleh masyarakat, mulai dari himpitan ekonomi, kenakalan remaja, pengaruh negatif globalisasi, stress, dan masih banyak lagi yang lainnya. Tentunya hal ini jika tidak disikapi dengan bijak oleh seseorang akan menjadikan hatinya menjadi goyah. Dan seseorang harus selalu menjaga hatinya agar tenang yang salah satunya adalah dengan mengingat Allah atau berdzikir.

Dalam diri manusia terdapat dua hal yang sangat berpengaruh terhadap perilaku manusia yakni "nafsu dan qalbu". Jika seseorang manusia tidak berdzikir (mengingat Allah), maka yang terjadi adalah kedzaliman, kemaksiatan dan lain sebagainya karena manusia akan cenderung pada pemenuhan nafsu secara berlebih-lebihan. ${ }^{1}$ Dzikir merupakan salah satu aspek yang sangat strategis dalam ibadah.

Adapun keutamaan dalam berdzikir adalah hati akan menjadi tentram, pikiran pun akan jernih. Dengan begitu segala sesuatu yang dilakukan akan menjadi baik. Dengan selalu mengingat Allah, maka akan menjadikan manusia mampu memahami makna atau hakikat hidupnya. Sebagaimana firman Allah dalam Al-Qur'an surat ar-Ra'du ayat 28:

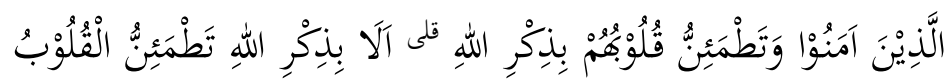

"(Yaitu) orang-orang yang beriman dan hati mereka manjadi tenteram dengan mengingat Allah. Ingatlah, hanya dengan mengingati Allah-lah hati menjadi tenteram." 2 [Q.S. ar-Ra'du: 28]

Dzikir yang bermanfaat adalah yang dibaca dengan kehadiran hati.Adapun selain itu, sedikit manfaatnya.Karena, yang dimaksud adalah berdialog dengan-Nya dan itu dapat dicapai dengan mengekalkan dzikir dengan kehadiran hati. ${ }^{3}$ Proses dzikir tidak hanya berhenti sampai disitu saja, tetapi bagaimana merealisasikan manfaat dzikir dalam kehidupan

\footnotetext{
2003), 13.

1 Muhammad Arifin Ilham, Menggapai Kenikmatan Dzikir, (Depok: Intuisi Press, 201

2 Penerbit Toha Putra, Al-Qur'an dan Terjemahnya, (Semarang: PT Toha Putra, tt)

${ }^{3}$ Al-Ghazali, Mutiara Ihya Ulumuddin: Terj. Mukhatasar Ihya Ulumuddin, (Bandung: Mizan, 2008), 125.
}

98 JURNAL LISAN AL-HAL 
sehari-hari khususnya dalam dunia pendidikan yaitu berupa taqwa dan akhlaqul karimah.

Sikap dzikir yang disebutkan oleh Amin Syukur yaitu, Minna Allah (dari Allah), Illa Allah (kecuali Allah), Billahi (dengan izin Allah), Ma'a Allah (yakin kepada Allah), dan Ila Allah (kembali kepada Allah). Proses dzikir tidak hanya berhenti sampai disitu saja, tetapi bagaimana kita merealisasikan manfaat dzikir dalam kehidupan sehari-hari khususnya dalam dunia pendidikan yaitu berupa taqwa dan akhlaqul karimah.

Dampak dzikir jika diresapi dengan hati serta dilaksanakan dengan penuh keikhlasan akan mempunyai dampak 1) sehat jasmani dan rohani serta 2) akan terbentuknya akhlak yang baik. Hal ini sesuai dengan tujuan dari pendidikan Islam yang mana menurut Muhammad Athahiyah alAbrasyi, tujuan Pendidikan Islam adalah tujuan yang telah ditetapkan dan dilakukan oleh Nabi Muhammad SAW sewaktu hidupnya, yaitu pembentukan moral yang tinggi, karena pendidikan moral merupakan jiwa pendidikan Islam sekalipun tanpa mengabaikan pendidikan jasmani, akal, dan ilmu praktis.

\section{B. Konsep Dzikir}

Dzikir dalam arti menyebut nama Allah, yang diamalkan secara rutin, atau biasa disebut wirid, adalah termasuk ibadah mahdhah, yaitu ibadah langsung kepada Allah. Sebagai ibadah mahdhah, maka dzikir jenis ini terikat dengan norma-norma ibadah langsung kepada Allah.Secara sederhana dzikir diartikan "mengingat". ${ }^{4}$ Yang dimaksud adalah ingat kepada Allah di dalam hati disertai menjalankan semua perintah dan menjauhi larangan-larangan-Nya.Ingat itu ada kalanya dengan hati atau dengan lidah, ingat dari kelupaan dan ketidaklupaan, serta sikap menjaga sesuatu dalam ingatan.Istilah dzikir Allah dalam Islam secara umum diartikan "mengingat Allah" atau "menyebut asma Allah".

Menurut Amin Syukur dzikir adalah sebagai salah satu bentuk ibadah makhluk, khususnya manusia kepada Allah dengan kesadaran mengingat kepada-Nya. Dimana ketika dzikir melibatkan antara rasa dan otak secara bersamaan maka akan mempunyai efek yang sangat luar biasa. Manfaatnya adalah menarik energi positif yang bertebaran di udara agar energi tersebut bisa masuk tersirkulasi ke seluruh bagian tubuh pelaku dzikir.Manfaatnya untuk menjaga keseimbangan suhu tubuh agar tercipta suasana jiwa yang tenang, damai, dan terkendali. Hal ini insya Allah akan menentukan kualitas ruh seseorang. Sebaliknya orang yang lalai, akan

${ }^{4}$ Samsur Munir Amin dan Haryanto Al-Fandi, Energi Żikir, 11.

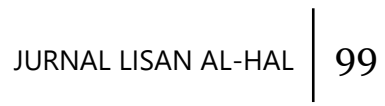


menarik energi negatif, yang biasa menyebabkan seseorang jatuh sakit, dan sebagainya.

Jika mencermati ayat-ayat Al-Qur'an yang berkaitan dengan dzikir, dapat dipahami bahwa dzikir itu membentuk akselerasi mulai dari renungan, sikap, aktualisasi sampai kepada kegiatan proses alam. Semua itu menghendaki terlibatnya dzikir tanpa boleh alpa sedikit pun, dan merupakan jaminan berakarnya ketenangan dalam diri. Kalau diri selalu terhubung dalam ikatan ketuhanan, maka akan tertanamlah dalam diri seseorang sifat-sifat ketuhanan yang berupa ilmu, hikmah dan iman. ${ }^{5}$

Berdzikir dan berdo'a sangat membantu menciptakan suasana hati yang tenang dan tenteram.Dengan catatan, kita menjalankannya dengan penuh keyakinan dan penuh rasa optimis. Tidak boleh ada keraguan sedikit pun, dengan keyakinan itulah insya Allah doa kita akan mudah terkabul. Di sinilah pentingnya mengatur mental dan menata hati.Dikatakan oleh Amin Syukur bahwa ketenangan bisa menghasilkan metabolisme, pertumbuhan, dan perkembangan tubuh manusia menjadi sangat normal, tenang, dan teratur. ${ }^{6}$ Akan tetapi, hidup tidak selamanya memberi kita kenyamanan dan ketenteraman. Ada saja momen atau kejadian yang mendorong munculnya stress dalam diri kita. Artinya kita tidak mungkin terhindar dari stress.Agar kondisi metabolisme dalam tubuh kita tetap dalam kondisi stabil, maka jalan yang hendaknya kita tempuh adalah dengan mengelola kemarahan dan memanaje stress setepat mungkin.Hendaknya kita menerima kenyataan ada adanya (qana'ah), dan tidak melakukan tindakan yang berlebihan, inilah yang diajarkan oleh Islam.Demikian pula sikap-sikap sufistik lainnya seperti husnudzan, Wira'i, zuhud, sabar, ridha, tawakal dan lain sebagainya.Semua itu merupakan anak tangga menuju hidup yang stabil dan seimbang. Dengan menghayati dan mengamalkannya setiap hari, maka akan sangat membantu kita untuk mewujudkan hidup yang dinamis.

Dikatakan oleh Amin Syukur bahwa peran jiwa kita sangat berpengaruh dalam melakukan penyembuhan terhadap penyakit fisik maupun psikis.Pengobatan dari medis atau pengobatan dari luar sifatnya hanya membantu saja. Dalam hal ini, bahwa faktor utama penyembuhan, khususnya sakit psikis itu sebagian berasal dari dalam, yaitu sikap batin (60\%), sedangkan selebihnya (40\%) adalah faktor lingkungan, seperti faktor dari keluarga, obat dan lain sebagainya.

${ }^{5}$ Amin Syukur dan Fatimah Utsman, Terapi Hati dalam Seni Menata Hati, (Semarang, Pustaka Nuun, 2009), 58.

${ }^{6}$ Amin Syukur, Dzikir Menyembuhkan Kankerku, (Jakarta: Hikmah, 2008),166.

$100 \mid$ JURNAL LISAN AL-HAL 
Untuk menciptakan hal-hal yang positif itu, diperlukan upaya tertentu seperti dzikir dan berdoa.Semua itu dilakukan mengacu pada diagnosa penyakitnya. Setiap doa yang disampaikan harus disesuaikan dengan sakitnya, misalnya sedang mengalami stress, maka doanya itu supaya diberikan ketenangan hati untuk menghadapi berbagai masalah yang sedang dihadapinya. Di samping itu, dianjurkan pula untuk bertadabbur dan muhasabah, baik terhadap alam maupun diri sendiri atas kesalahan-kesalahan yang telah dilakukan. Selanjutnya melakukan pengenangan terhadap masa lalu, berfikir positif (husnu dzan) dan tidak berfikir negatif terhadap orang lain. Berfikir positif itu ditujukan baik terhadap diri sendiri, orang lalin, maupun terhadap Allah SWT.Selain itu, kita juga berupaya menghapus perasaan bersalah, menghapus rasa iri hati, rasa takut dan sebagainya dari sifat-sifat yang tercela.Hal ini sesuai dengan teori psikcho-neoro-indokrinologi dan psikcho-neoro-imunologi yang dikemukakan oleh Dadang Hawari. Dalam teori tersebut dijelaskan bahwa kondisi psikhis akan mempengaruhi syaraf dan syaraf akan mempengaruhi kelenjar dan kelenjar akan mengeluarkan cairan dalam tubuh yang disebut endokrin, dan cairan ini akan mempengaruhi kekebalan tubuh.

Dari sini jelas bahwa dzikir bisa dimaknai merenung dan muhasabah, yakni meneliti diri sendiri.Pasalnya dalam Berdzikir, manusia diajak untuk mengenal dirinya sendiri.Dengan keyakinan yang kuat, bahwa berdo"a, berdzikir dan bertawakal mempunyai kekuatan yang luar biasa didalamnya ada kekuatan Psikoreligius.Dengan kata lain kekuatan spiritual/ kerohanian/ ke-Tuhanan, melalui sistem syaraf yang kemudian diteruskan ke kelenjar hormonal, memulihkan keseimbangan hormonal serta meningkatkan imunitas tubuh.

\section{Biografi Amin Syukur}

Amin Syukur, pria kelahiran Gresik 17 Juli 1952 yang menjadi seorang guru besar tasawuf di IAIN Walisongo Semarang lahir dari pasangan orang tua H. Abdus Syukur, (almarhum) dan Hj. Umi Kulsum (almarhumah) di desa Kali Rejo dukuh Gresik. Desa yang lingkungannya semuanya beragama Islam.Walaupun di desanya tidak ada pondok pesantren, namun kegiatan agama setiap harinya seolah-olah seperti pondok pesantren.Dari siang hingga malam hari, banyak anak-anak yang belajar mengaji Alquran maupun ibadah kepada ustadznya.Amin Syukur dibesarkan dalam lingkungan masyarakat dan keluarga Nahdlatul Ulama 
(N.U.) yang ketat dalam urusan agama. ${ }^{7}$ Sebelum menikah dengan Umi Kulsum, ayahnya telah menikah dengan Munassarah (almarhumah) dan dikaruniai lima orang anak, namun empat di antaranya telah meninggal dunia, sedangkan yang masih hidup ialah Abdul Mujib, kakaknya. Sejak kecil Amin Syukur merasa selalu diistimewakan, mungkin karena anak pertama dari tujuh bersaudara. Kedua orang tuanya akan melakukan apa pun untuk kebaikan dan kesenangan buah hatinya. Kebanggaan beliau terhadap orang tuanya terletak pada perhatian dan teladannya dalam membimbingnya sejak kecil agar mendedikasikan hidupnya pada ibadah.Walaupun pendidikan ayahnya yang hanya mengampu pendidikan sampai kelas 3 Madrasah Ibtidaiyah serta ibunya yang tidak sempat mengenyam dunia pendidikan, namun perhatian orang tuanya terhadap pendidikan Amin Syukur begitu besar.

Selanjutnya berkaitan masalah riwayat pendidikan yang beliau tempuh, Amin Syukur memulai pendidikannya di Madrasah Islamiyah desa Sembungan Kidul, Gresik.Satu tahun setelah menyelesaikannya beliau mengikuti kakaknya Abdul Mujib untuk mondok di al-Karimi Tebuwung, di pondok ini beliau hanya sempat mengenyam pendidikan selama satu tahun karena kakaknya sudah lulus.Setelah dari pesantren alKarimi Amin Syukur melanjutkannya di pondok pesantren Ihyaul 'Ulum Gresik dengan pengasuh K.H. Ma'shum.Disini beliau tidak tinggal di pesantren, tetapi menjadi santri kalong atau lazim disebut santri nglaju.Setiap harinya Amin Syukur berjalan kaki dari rumah menuju pesantren, kadang-kadang juga naik sepeda onthel.

Pendidikan dasar ditempuhnya di Madrasah Ibtidaiyyah (MI) Ponpes Ihya'ul Ulum Gresik, dan kemudian melanjutkan di Sekolah Menengah Pertama (SMP) Darul 'Ulum dan tingkat atasnya ditempuh di Sekolah Menengah Atas (SMA) Darul 'Ulum Jombang. Amin Syukur di Darul 'Ulum menjalani tiga pola pendidikan sekaligus, yakni pendidikan pesantren, pendidikan madrasah dan sekaligus pendidikan umum kemudian melanjutkan ke perguruan tinggi di Universitas Darul 'Ulum (UNDAR) mengambil fakultas Alim 'Ulama yang sekarang menjadi fakultas Ushuluddin UNDAR, disini tingkat III berhasil beliau selesaikan, tingkat baccaloureat pada pertengahan tahun 1976. Sehingga bila dihitung, total waktu yang beliau habiskan "nyantri" di pondok pesantren adalah sekitar 9,5 tahun. Selama 3 tahun dibangku sekolah Menengah Pertama (SMP) Darul Ulum, 3 tahun di bangku Sekolah Menengah Atas (SMA) Darul Ulum, dan 3,5 tahun ditempuhnya ketika kuliah di Universitas Darul Ulum

${ }^{7}$ Amin Syukur dan Fathimah Utsman, Op.Cit...,145

$102 \mid$ JURNAL LISAN AL-HAL 
(UNDAR). Waktu 3,5 tahun terpaksa beliau tempuh karena kuliah di perguruan tinggi swasta. Tiga tahun kuliah, kemudian yang setengah tahunnya menunggu ujian negara.

Selama di UNDAR pula, Amin Syukur sudah mulai menyibukkan diri dalam aktivitas intra-ekstra kampus serta berbisnis.Beliau juga sempat merasakan bagaimana kesibukan menjadi ketua Departemen Pendidikan dan Pengajaran di Dewan Mahasiswa UNDAR dan ketua umum Senat Mahasiswa Fakultas Ushuluddin UNDAR. Berkat kekompakan dan saling bantu dari pengurus yang lain, banyak program yang bisa terlaksana dengan baik dan tepat waktu, meskipun tidak ada anggaran tetap dan pasti dari lembaga yang digelutinya. Selain itu, Amin Syukur juga aktif di organisasi ekstra kampus, waktu itu beliau aktif di Komite Nasional Pemuda Indonesia (KNPI) kabupaten Jombang.

Diantara karya-karya beliau meliputi :

1. Amin Syukur. 2002. Menggugat Tasawuf "Sufisme dan Tanggung Jawab sosial Abad 21, Yogyakarta: Pustaka Pelajar

2. Amin Syukur. 2009. Terapi Hati: Dalam Seni Menata Hati, Semarang: Pustaka Nuun bekerja sama dengan Lembkota Semarang.

3. Amin Syukur. 2006. Insan Kamil "Paket Pelatihan Seni Menata Hati", Semarang: CV. Bima Sakti.

4. Amin Syukur. 2004. Intelektualisme Tasawuf: Studi Intelektualisme Tasawuf Al-Ghazali, Lembkota Semarang bekerja sama dengan Pustaka Pelajar Yogyakarta

5. Amin Syukur. 2001. Tasawuf dan Krisis, Yogyakarta: Pustaka Pelajar bekerja sama dengan Walisongo Press.

6. Amin Syukur. 2006 Insan Kamil, Semarang: CV. Bima Sejati.

7. Amin Syukur. 2002. Menggugat Tasawuf: Sufisme dan Tanggung Jawab Sosial Abad 21, Yogyakarta: Pustaka Pelajar.

8. Amin Syukur. 2006. Pengantar Studi Islam, Semarang: Lembkota Semarang

9. Amin Syukur. 2010. Sufi Healing: Terapi dalam Literatur Tasawuf, tk: tp

10. Amin Syukur. 2006. Tasawuf Bagi Orang Awam: Menjawab Problem Kehidupan, LPK-2 Suara Merdeka Semarang bekerja sama dengan Pustaka Pelajar Yogyakarta.

11. Amin Syukur. 2003. Tasawuf Kontekstual: Solusi Problem Manusia Modern, Yogyakarta: Pustaka Pelajar.

12. Amin Syukur. 2004. Tasawuf Sosial, Yogyakarta: Pustaka Pelajar.

13. Amin Syukur. 2008. Dzikir Menyembuhkan Kankerku, Jakarta: Hikmah.

14. Amin Syukur. 1997. Żuhud di Abad Modern, Yogyakarta: Pustaka

$$
\text { JURNAL LISAN AL-HAL } 103
$$


Pelajar.

\section{Konsep Zikir Menurut Amin Syukur}

Dalam Islam, dzikir merupakan tiang penopang yang sangat kuat di jalan menuju Allah. Tidak bisa seorang mencapai Tuhan kecuali dengan terus menerus melakukan dzikir.Oleh karena itu hakikat dzikir, menurut Amin Syukur memiliki pengertian bahwa dzikir adalah sebagai salah satu bentuk ibadah makhluq, khususnya manusia kepada Allah dengan kesadaran mengingat kepada-Nya. Dimana ketika dzikir melibatkan antara rasa dan otak secara bersamaan maka akan mempunyai efek yang sangat luar biasa.

Dzikir dalam arti menyebut nama Allah, yang diamalkan secara rutin, atau biasa disebut wirid, adalah termasuk ibadah mahdhah, yaitu ibadah langsung kepada Allah. Sebagai ibadah mahdhah, maka dzikir jenis ini terikat dengan norma-norma ibadah langsung kepada Allah.

Secara sederhana dzikir diartikan "mengingat". ${ }^{8 Y a n g}$ dimaksud adalah ingat kepada Allah di dalam hati disertai menjalankan semua perintah dan menjauhi larangan-larangan-Nya.Ingat itu ada kalanya dengan hati atau dengan lidah, ingat dari kelupaan dan ketidaklupaan, serta sikap menjaga sesuatu dalam ingatan.Istilah dzikir Allah dalam Islam secara umum diartikan "mengingat Allah" atau "menyebut asma Allah".

Menurut Amin Syukur dzikir adalah sebagai salah satu bentuk ibadah makhluk, khususnya manusia kepada Allah dengan kesadaran mengingat kepada-Nya. Dimana ketika dzikir melibatkan antara rasa dan otak secara bersamaan maka akan mempunyai efek yang sangat luar biasa. Manfaatnya adalah menarik energi positif yang bertebaran di udara agar energi tersebut bisa masuk tersirkulasi ke seluruh bagian tubuh pelaku dzikir.Manfaatnya untuk menjaga keseimbangan suhu tubuh agar tercipta suasana jiwa yang tenang, damai, dan terkendali. Hal ini insya Allah akan menentukan kualitas ruh seseorang. Sebaliknya orang yang lalai, akan menarik energi negatif, yang biasa menyebabkan seseorang jatuh sakit, dan sebagainya.

Untuk itu Amin Syukur membagi dzikir ke dalam empat bentuk: ${ }^{9}$ Pertama, dzikir qauli/dzikir dengan lisan, dzikir lisan dapat dimaknai dengan dzikir yang diucapkan dengan lisan dan dapat didengar oleh telinga, baik oleh orang yang bersangkutan maupun orang lain.

8Samsur Munir Amin dan Haryanto Al-Fandi, Energi Żikir, 11.

9 Amin Syukur dan Fatimah Utsman, Insan Kamil "Paket Pelatihan Seni Menata Hati”, (Semarang: CV. Bima Sakti, 2006), 30.

104 JURNAL LISAN AL-HAL 
Menyebut dan mengingat Allah dengan lisan dapat dibedakan menjadi dua macam, yakni dengan suara pelan (sirr) dan dengan suara keras (jahr) seperti istighasah atau do'a bersama yang sering dilakukan kelompok organisasi keislaman.Kedua, dzikir qalbi.Dzikir qalbi adalah aktivitas mengingat Allah yang dilakukan dengan hati, artinya sebutan itu dilakukan dengan ingatan hati.Dzikir qalbu juga dapat dimaknai dengan melaksanakan dzikir dengan lidah dan hati, maksudnya lidah menyebut lafal tertentu dari lafaz dzikir dan hati mengingat dengan meresapi maknanya.Ketiga, dzikir ruh, artinya seluruh jiwa raganya tertuju untuk selalu ingat kepada Allah SWT tanpa hitungan.Prinsip dari dzikir ini adalah dari Allah, milik Allah, dengan bantuan Allah dan kepada Allah. Jika prinsip ini sudah tertanam dalam jiwa seseorang tentunya kehidupan sehari-harinya akan dihiasi dengan kedamaian dan ketenangan. Keempat, dzikir fi'ly atau dzikir dengan melakukan perbuatan. Dzikir ini merupakan refleksi dari ketiga dzikir sebelumnya, dengan selalu mengingat Allah senantiasa membuat seseorang akan melakukan perbuatan atau amal shalih dengan perasaan ikhlas karena dengan prinsip yang telah disebutkan sebelumnya otomatis semuanya akan dipasrahkan kepada Allah SWT.

Dari keempat bentuk di atas, nampak konsep dzikir yang diterapkan Amin Syukur mempunyai dampak psikologis seseorang, yakni dzikir mengandung pengakuan mental dan emosional bahwa segala sesuatu adalah manifestasi dari sumber tunggal. Sebagaimana menurut Arifin Ilham bahwa hanya dengan selalu berdzikir kepada Allah, maka kesadaran batin seseorang akan semakin hidup dan peka untuk senantiasa tetap melakukan kebaikan dan perbaikan sebagai wujud amal shaleh. ${ }^{10}$

Ibnu Atta sebagaimana yang ditulis dalam Ensiklopedia Islam menjelaskan bahwa tingkatan dzikir yang paling tinggi ialah dzikir haqiqi, yaitu dzikir yang dilakukan oleh seluruh jiwa raga, lahiriah dan batiniah, kapan dan dimana saja, dengan memperkuat upaya untuk memulihkan seluruh jiwa raga dari larangan Allah SWT dan mengerjakan apa yang diperintahkan-Nya, selain itu tiada yang diingat selain Allah SWT. ${ }^{11}$

Dengan demikian empat bentuk konsep dzikir yang dirumuskan Amin Syukur cukup tepat, yakni di dalam mengamalkan dzikir perlu

10 Muhammad Arifin Ilham, Menzikirkan Mata Hati: Pesan-pesan Spiritual Penjernih Hati, (Depok: Intuisi Press, 2004), 62.

11 Dewan Redaksi Ensiklopedia Islam, Ensiklopedia Islam, (Jakarta: PT. Ichtiar Baru van Hoeve, 2002), 235. 
melalui proses, dari menggerakkan lidah yang disertai niat dipindahkan ke pikiran, dari pikiran ke perasaan dan tingkat personalitas yang dalam, sampai realitasnya yaitu mengakar di dalam hati serta diwujudkan dalam bentuk amal perbuatan yang baik.

Sementara praktik dan bacaan dzikir yang diamalkan Amin Syukur umumnya tidak jauh beda dengan dzikir lainnya. Namun di sini agar bisamenangkap makna khusyu', merasakan dan menghayati apa yang dibaca (dzikir) terlebih dahulu pikiran dan perasaan harus dikosongkan. Sudah barang tentu semuanya itu diawali dengan wasilah dengan amal shalih, berupa shalat baik fardhu maupun sunnah utamanya shalat malam.

Berikut bacaan dzikir yang diterapkan Amin Syukur, membaca surat al-Fatihah yang berarti pintu pembuka. Ini dilakukan dengan berharap dibukakannya pintu hati dan pikiran yang bersangkutan oleh Allah SWT, sehingga terbuka pula pintu petunjuk, ampunan, rahmat, dan ma'rifat.Dalam hal ini bacaan Al-Fatihah dibaca satu kali.

Menyusul setelah suratal-Fatihah, selanjutnya membaca surat alIkhlash. Surat ini mengajarkan manusia untuk belajar mengendalikan hati agar berjalan lurus sesuai dengan yang dikehendaki Allah SWT.Surat AlIkhlash ini lebih mengarah kepada perbaikan aqidah dan akhlaq seseorang dengan tuntunan Allah SWT.Oleh karena itu, setiap perbuatan sudah tentunya disandarkan hanya kepada Allah SWT. Sebagaimana yang diungkapkan Samsur Munir Amin dan Haryanto Al-Fandi bahwa dengan membaca surat al-Ikhlash dapat mengingatkan kepada seseorang akan kemurnian Żat Allah yang tunggal, yang menjadi tempat bergantung baagi seluruh makhluk hidup. ${ }^{12}$

Kemudian surah Al-Falaq dan surah An-Nās. Dua surat ini dimaknai sebagai perisai bagi kaum muslimin. Dengan membaca surat ini ditujukan agar sifat-sifat seperti riya', dengki, hasud, jahat, dan tabiat-tabiat buruk yang ada dalam hati dapat hilang. Hal ini relevan dengan apa yang dikarakan oleh Zakiyah Daradjat bahwa surat Al-Falaq itu mengajarkan bagaimana seharusnya manusia memusatkan permohonan perlindungan kepada Allah SWT dari semua makhluk ciptaan-Nya, dari kegelapan malam, dan tukang sihir dan dari kedengkian seseorang. Sedangkan surat An-Nās merupakan permohonan perlindungan dari kejahatan setan lewat jin dan manusia. ${ }^{13}$

Selanjutnya membaca surat al-Insyirah, surat ini mengandung

${ }^{12}$ Samsur Munir Amin dan Haryanto Al-Fandi, Op.Cit..., 118.

13 Zakiyah Darajat, Do'a Penunjang Semangat Hidup, (Jakarta: CV Ruhama, 1994), 49.

106 JURNAL LISAN AL-HAL 
makna bahwa ketika manusia tunduk, menyerah, dan berusaha untuk mengusir sifat-sifat syaitan di dalam hati kemudian diganti dengan sifatsifat Tuhan. Dari beberapa ayat Al-Qur'an yang dikonsepkan oleh Amin Syukursebagai dzikir, nampaknya cukup beralasan.Karena dzikir yang paling utama adalah membaca Al-Qur'an. Al-Qur'an juga merupakan segala sumber hukum dalam Islam, membacanya bernilai ibadah bahkan merupakan ibadah yang sangat mulia dan seutama-utamanya dzikir kepada Allah. Alquran juga sebagai penawar dan obat yang paling baik bagi segala penyakit baik fisik maupun psikis.

Setelah membaca ayat-ayat Al-Qur'an, dzikir dilanjutkan dengan membaca istighfar, hauqalah, tahlil, asmaul husna, shalawat, tausiyah.Istighfar dapat dimaknai dengan menundukkan hati, jiwa dan pikiran kepada Allah seraya memohon ampunan terhadap-Nya dari segala dosa dan salah yang telah dilakukan, baik dosa yang dilakukan dengan sengaja maupun karena lupa.

Hauqalah dimaknai dengan isyarat bahwa seseorang telah yakin bahwa sesunguhnya di dunia ini tidak ada daya dan kekuatan yang berkuasa untuk memberikan perlindungan dan pertolongan selain kekuatan Allah SWT.Tahlil merupakan bacaan dzikir yang sangat istimewa dan utama, tahlil juga merupakan sebaik-baik bacaan dzikir. Tahlil dimaknai dengan penegasan bahwa seseorang itu benar-benar bersedia mengakui bahwasanya Allah adalah Tuhan yang Mahatunggal yang palilng layak disembah dan dimintai pertolongan.Asmāul husna merupakan nama-nama yang Agung yang berjumlah sembilan puluh sembilan, di mana dari setiap nama adalah gambaran tentang sifat-sifat yang dimiliki Allah SWT. Dilanjutkan dengan membaca shalawat Nabi denganharapan diberikan rahmat oleh Allah SWT atas dirinya.

Selanjutnya dengan tausiyah, dimaknai dengan renungan serta mencari solusi atas masalah yang dihadapi melalui media tanya jawab. Menjelang akhir dzikir, dilanjutkan do'a yang intinya meminta agar setiap dosa dimaafkan Allah, setiap tobat diterima Allah SWT., do'a merupakan faktor yang paling penting dalam menolak sesuatu yang tidak disenangi dan memperoleh sesuatu yang diinginkan. Dengan kata lain do'a mampu membendung dan mencegah turunnya musibah.

Sehubungan dengan konsep dzikir berjama'ah yang diterapkan Amin Syukur mempunyai corak dakwah-religius-psikologis.Dipandang memiliki nilai dakwah, karena sebagaimana fungsi dan tujuannya, meninggalkan kemungkaran.Bukti religius adalah terletak pada keterkaitan konsep pembersihan diri dengan Allah SWT dan hal-hal yang bersifat transendental (seperti dorongan syaitan, dorongan malaikat, nilai- 
nilai keutamaan akhlak) yang berasal dari ajaran agama, wahyu, kebahagiaan akhirat dan sebagainya. Sementara indikasi corak psikologisnya adalah manusia sebagai pusat kajiannya yang menjadi tujuan Amin Syukur dalam berdzikir, sehingga di sini agama sebagai pondasi landasan normatifnya.

\section{E. Analisis Konsep Zikir Menurut Amin Syukur Dan Relevansinya Dengan Tujuan Pendidikan Islam}

Rumusan tentang tujuan pendidikan Islam tampak bahwa pendidikan Islam memiliki beberapa tujuan.Di antaranya berupaya memberikan pelayanan pada aspek spiritual.Artinya pendidikan Islam berupaya mewujudkan manusia yang taat kepada Allah. Hal ini sesuai tujuan penciptaan manusia di bumi, sebagaimana firman Allah dalam Q.S. adz-Dzariyat/51: 56 :

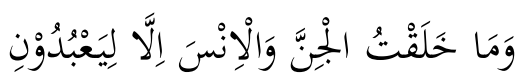

"Dan aku tidak menciptakan jin dan manusia melainkan supaya mereka mengabdi kepada-Ku" [Q.S Adz-Dzariyat: 56]

Selain memberikan bagi berkembangnya aspek spiritual, pendidikan Islam juga berusaha menyiapkan manusia menjadi khalifah di bumi.Oleh karenanya pendidikan Islam berusaha memberikan pelayanan bagi berkembangnya aspek jasmani dan intelektual.Kedua aspek ini dikembangkan sebagai bekal manusia dalam menjalankan tugas kekhalifahan tersebut.

Mencapai tujuan pendidikan Islam merupakan tugas bersama antara elemen sekolah, masyarakat, dan keluarga. Untuk itu agar tujuan pendidikan Islam dapat tercapai setelah proses pendidikan Islam bisa dilakukan dengan selalu mengingat Allah (dzikir). Oleh karena itu diperlukan kerja sama antara pihak-pihak tersebut, dan untuk dapat menerapkannya (berdzikir) diperlukan pelatihan dan pengawasan.

Seperti yang dikatakan oleh Amin Syukur bahwa pendidikan Islam hendaknya tidak hanya memperhatikan ranah kognitif saja tetapi juga afektif dan psikomotorik, menggunakan metode-metode dan pendekatan yang sesuai dengan materi dan yang penting lagi dibutuhkan keteladanan, adapun mengenai pengawasan itu menjadi tanggung jawab bersama.

Kalau dicermati, kegagalan pendidikan dewasa ini karena prosesnya masih menghadapi beberapa masalah, yaitu:

1. Perbedaan penekanan antara pengertian "pendidikan" yang menekankan aspek akhlaq dan budi, dan pengertian "pengajaran" yang menekankan konsumsi otak. Proses pendidikan sekarang lebih 
cenderung kepada istilah kedua. Perubahan istilah pendidikan menjadi pengajaran tersebut cenderung pula untuk mengembangkan aspek kognitif dan psikomotorik.Padahal keberhasilan pendidikan dalam bentuk tingkah laku meliputi ketiganya secara integral.

2. Konsep baru sekarang lebih banyak mengejar materi. Akibatnya, asal memenuhi tugasnya secara formal guru enggan bertanggung jawab secara moral.

3. Tujuan utama peserta didik dalam belajar ialah untuk memperoleh ijazah dan selanjutnya melamar pekerjaan. Inilah penyakit yang melanda dunia pendidikan yang mendapat perhatian besar dari pemerintah.

4. Kurikulum pendidikan yang belum terarah dan terpadu, setiap bidang studi tidak disusun dengan mengaitkan antara bidang studi yang satu dengan bidang studi yang lainnya. Lebih-lebih ilmu kauniyah dengan ilmu-ilmu ilahiyah.

5. Kurang adanya suasana kasih sayang antara guru dan murid dalam interaksi pendidikan.

6. Pendidikan agama hanya berkisar dalam ilmu kalam dan fiqih dalam arti sempit. Maksudnya, kurang adanya penekanan dalam penerapan agamanya. Kurikulumnya memisahkan antara aspek iman, Islam, dan ihsan, sehingga dikenal adanya guru tauhid, guru fiqih, guru ibadah, guru syari'ah dan lain-lain.

Sebenarnya, manusia itu bukan semata-mata fisik-material saja, tetapi di balik itu ia memiliki dimensi lain, yang dipandang sebagai hakekat manusia, yakni dimensi rohaniah (spiritual). Dimensi fisikmaterial dan dimensi mental-spiritual saling berinteraksi dan saling mempengaruhi. Oleh sebab itu, manusia tidak mungkin mampu menjalani hidup tanpa membekali kedua unsur yang ada pada dirinya itu. Ruhaniah manusia yang menopang kehidupan jasmaniahnya tidak boleh diabaikan di dalam kehidupan. Kalau dimensi fisik dapat hidup dan merasa senang dengan makanan yang bersifat material, maka rohaniah manusia akan hidup dan merasa tenteram dengan makanan yang bersifat spiritual. Iman dan keyakinan adalah makanan rohaniah manusia.Iman dan keyakinan mengambil institusi dalam bentuk dzikir dan shalat. Dzikir dan shalatlah yang akan memuaskan dahaga batin manusia.

Dengan demikian, dzikir mempunyai makna yang penting bagi kehidupan setiap insan.Oleh sebab itu sebenarnya tidak hanya menyangkut spiritual manusia, tetapi juga menyangkut fisikbiologis.Kendati begitu, qalbu (roh, spiritual) manusia dipandang sebagai unsur pertama yang mendapat pengaruh makna dzikir, karena aktifitas

$$
\begin{array}{l|l}
\text { JURNAL LISAN AL-HAL } & 109
\end{array}
$$


dzikir itu sendiri bertitik awal dari qalbu manusia.Ajaran Islam menyatakan secara tegas bahwa Nabi Muhammad SAW diutus oleh Allah SWT kepada manusia adalah untuk menyempurnakan nilai akhlaq atau pendidikan budi pekerti, yang merupakan manifestasi dari taqwa dan tujuan pendidikan Islam.

Dzikir sebagai perbuatan ibadah, menurut Amin Syukur adalah sebagai salah satu bentuk ibadah makhluq, khususnya manusia kepada Allah dengan kesadaran mengingat kepada-Nya. ${ }^{14}$ Dimana ketika dzikir melibatkan antara rasa dan otak secara bersamaan maka akan mempunyai efek yang sangat luar biasa. Manfaatnya adalah menarik energi positif yang bertebaran di udara agar energi tersebut bisa tersirkulasi ke seluruh bagian tubuh pelaku dzikir.

Relevansi antara dzikir menurut Amin Syukur dengan tujuan pendidikan Islam sangat erat, keduanya tidak dapat dipisahkan.Kedekatan relevansi dzikir dengan pendidikan Islam sebenarnya disebabkan karena keduanya mempunyai hubungan timbal balik yang saling mengikat. Tujuan pendidikan Islam sendiri pada hakekatnya adalah terbentuknya insān kāmil dan penyadaran terhadap manusia di dunia sebagai khalifatullah fil ardhi, sedangkan dzikir sendiri merupakan salah satu jalan untuk mencapai insān kāmil maupun untuk mengingat akan tugas manusia sebagai hamba Allah (abdullah) karena dzikir itu berarti ingat kepada Allah. Sehingga semua perbuatan manusia itu merasa akan selalu diawasi oleh sehingga dalam menjalankan perbuatannya tidak akan keluar dari ajaran Islam. Insān Kāmil sendiri merupakan pancaran akhir dan citacita ideal yang diproyeksikan dan diharapkan dalam pendidikan Islam, sementara pendidikan Islam merupakan salah satu tujuan dan misi yang diemban yang hendak direalisasikan insān kāmil dalam aktivitas hidupnya.

Allah menciptakan manusia dengan sejumlah potensi dan menyediakan alam sebagai alat untuk mengembangkan ilmu pengetahuan dan teknologi.Dengan fasilitas tersebut manusia diharapkan dapat menembus cakrawala pandang yang tinggi dan menterjemahkannya, yang pada gilirannya menumbuhkan gagasan-gagasan baru yang bermanfaat bagi manusia dengan memfungsikan pikiranya serta menjadikan alat untuk mendekatkan diri kepada Allah dengan senantiasa berdzikir dan ingat kepada Allah yang telah menciptakannya.Pendidikan Islam sendiri juga mempunyai tujuan agar manusia hidup di dunia ini sesuai dengan fitrah yang telah Allah berikan kepadanya.Adapun di antara fitrah tersebut

\footnotetext{
${ }^{14}$ Amin Syukur, Żikir Menyembuhkan Kankerku, (Jakarta: Hikmah, 2008), 93.
} 
adalah:

\section{Ke-Tuhanan/ Tauhid}

Islam sebagai pandangan hidup yang berdasarkan nilai-nilai ilahiyah, baik yang termuat dalam Alquran maupun Sunnah Rasul diyakini mengandung kebenaran mutlak, sehingga secara aqidah diyakini oleh pemeluknya akan selalu sesuai dengan fitrah manusia. Artinya akan selalu memenuhi kebutuhan manusia kapan dan dimana saja. Karena pendidikan Islam adalah upaya normatif yang berfungsi untuk memelihara dan mengembangkan fitrah manusia, maka harus didasarkan pada nilai-nilai tersebut dalam menyusun teori maupun praktik pendidikan.

Dasar-dasar pendidikan Islam seperti kemanusiaan, kesatuan umat manusia, keseimbangan dan rahmatan lil 'ālamīn sebenarnya hanya merupakan penjabaran dari tauhid tersebut karena pada dasarnya seluruh nilai dalam Islam berpusat pada tauhid.Dengan dasar tauhid tampak kental sekali pendidikan Islam berlandaskan/berpusat pada Tuhan.Namun perlu disadari bahwa pemusatan pada Tuhan pada hakekatnya bukan untuk kepentingan Tuhan, tetapi sebaliknya justru sepenuhnya untuk kepentingan manusia.Artinya, semua kebaikan yang dilakukan manusia bukan untuk Tuhan tetapi kebaikan itu manfaatnya kembali pada manusia sendiri, baik untuk dirinya maupun masyarakat lingkungannya. Perintah Allah agar manusia senantiasa beribadah dan beramal shalih bukan untuk memenuhi kebutuhan Allah, Dia tidak butuh semua itu tetapi manusia-lah yang membutuhkan Allah karena Allah Maha Kaya, Maha Besar, Allah Maha Sempurna.

Secara terminologi tauhid berarti pengakuan terhadap ke-Esaan Allah.Tauhid merupakan fondasi seluruh bangunan ajaran Islam. Pandangan hidup tauhid bukan sekedar pengakuan akan ke-Esaan Allah, tetapi juga meyakini kesatuan penciptaan (unity of creation), kesatuan kemanusiaan (unity of mankind), kesatuan tuntunan hidup (unity of guidance), dan kesatuan tujuan dari kesatuan ketuhanan (unity of Godhead). Pengakuan atas keesaan Allah tersebut mengandung kesempurnaan kepercayaan kepada-Nya dari dua segi, yakni segi rububiyyah dan segi uluhiyyah.Tauhid rububiyyah ialah pengakuan terhadap ke-Esaan Allah sebagai Żat Yang Maha Pencipta, Pemelihara dan memiliki semua sifat kesempurnaan.Sedangkan tauhid uluhiyyah ialah komitmen manusia kepada Allah sebagai satu-satunya Żat yang dipuja dan disembah dan satu-satunya sumber nilai.Komitmen kepada Allah itu diwujudkan dalam sikap pasrah, tunduk dan patuh sepenuh hati, sehingga seluruh amal perbuatan bahkan hidup dan mati seseorang yang benar-

$$
\text { JURNAL LISAN AL-HAL } \mid 111
$$


benar bertauhid semata-mata hanya untuk Allah.

\section{Berfikir}

Manusia memiliki potensi berfikir, seringkali Allah menyuruh manusia untuk berfikir. Logikanya orang hanya disuruh berfikir karena ia memiliki potensi berfikir. Maka dapat dikatakan bahwa setiap manusia memiliki potensi untuk belajar akan informasi-informasi baru, menghubungkan berbagai informasi, serta menghasilkan pemikiran baru. Potensi berfikir ini berbeda antara manusia satu dibandingkan dengan manusia yang lain. Semakin besar potensi berfikir semakin besar kemampuan dalam menyerap dan mengembangkan pengetahuan.Mereka yang berpotensi besar memiliki kecenderungan ilmiah yang tinggi.

Contoh seorang yang memiliki bakat besar adalah Imam AlBukhari, sang ahli hadis terkenal. Pada awalnya. Al-Bukhari mempelajari ilmu fiqih,melihat bakat itu sang guru (Muhammad bin Hasan) yang ternyata penemu bakat berkata kepadanya: "pergi dan pelajarilah ilmuilmu hadis". Maka Al-Bukhari pun mengikuti petunjuk gurunya itu.Sejarah dan peradaban Islam telah mencatat bahwa beliau adalah orang terdepan dalam ilmu hadis, beliau adalah imam para ahli hadis.

Ada kalanya potensi yang dimiliki seseorang itu biasa saja, sehingga seseorang membutuhkan usaha yang lebih besar untuk memiliki penguasaan terhadap pengetahuan. Tentang usaha yang besar ada kalanya manusia menyesali mengapa dilahirkan dengan potensi yang biasa saja, satu hal yang patut untuk diingat adalah dibalik usaha yang besar itu ternyata terdapat janji akan balasan bukan hanya di dunia saja tapi juga di hari akhir. Sesuai dengan yang dikatakan Amin Syukur bahwa dengan berdzikir itu bisa mengambil suatu pelajaran, sebagaimana firman Allah dalam surat Ali-Imran: 190-191,

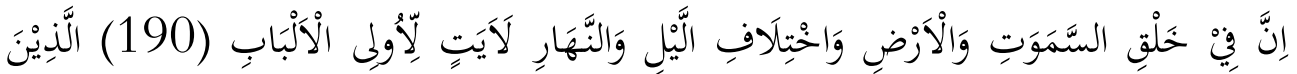

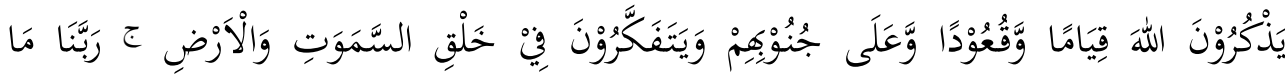

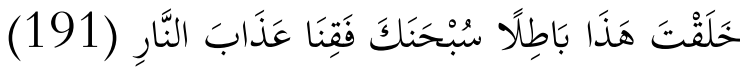

"Sesungguhnya dalam penciptaan langit dan bumi, dan silih bergantinya malam dan siang terdapat tanda-tanda bagi orang-orang yang berakal, (yaitu) orang-orang yang mengingat Allah sambil berdiri atau duduk atau dalam keadan berbaring dan mereka memikirkan tentang penciptaan langit dan bumi (seraya berkata): "Ya Tuhan Kami, Tiadalah Engkau menciptakan ini dengan sia-sia, Maha suci Engkau, Maka peliharalah Kami

$112 \mid$ JURNAL LISAN AL-HAL 
dari siksa neraka" [QS. Ali-Imran: 190-191]

Dari ayat tersebut dapat dipahami bahwa Allah memerintahkan manusia untuk berdzikir melalui penciptaan-Nya, dan ayat ini juga menjelaskan tentang perintah menggunakan akal untuk mengetahui kebesaran Allah.

\section{Emosi}

Potensi yang lain adalah potensi dalam bidang afeksi atau emosi. Setiap manusia memiliki potensi cita-rasa, yang dengannya manusia dapat memahami perasaan orang lain, memahami perasaan makhluk-makhluk lain, memahami suara alam, ingin mencintai dan dicintai, memperhatikan dan diperhatikan, menghargai dan dihargai maupun cenderung kepada keindahan.

Nabi Muhammad SAW sangat menghargai orang-orang di sekitarnya yang memiliki kemampuan merasakan kehadiran lingkungan itu dengan jernih. Sebagian manusia memiliki potensi yang besar untuk belajar akan hal-hal yang mementingkan perasaan. Orang yang berpotensi dalam bidang musik mampu mempelajari musik dengan cepat dan mampu untuk mengembangkan diri dalam bidang musik (menciptakan kreasi baru dalam bidang musik).Ada orang yang memiliki kemampuan yang sangat cepat meniru gerakan tari dengan lemah gemulai dan menghasilkan kombinasi baru gerak tari. Ada orang yang mampu melukis dengan bagus dan dilakukan dengan cara yang baru.

Amin Syukur menjelaskan bahwa manfaat dari dzikir adalah sebagai terapi jiwa/ kontrol diri.Tidak dapat dipungkiri bahwa banyak sekali permasalahan yang dihadapi oleh peserta didik yang mana dapat menimbulkan stres. Misalnya saja, gagal tidak naik kelas, tidak lulus dalam ujian nasional maupun yang lainnya. Tentunya jika hal semacam ini tidak disikapi denganbijak oleh setiap peserta didik, maka yang timbul adalah kekacauan batin. Akan tetapi jika peserta didik sudah dibekali dengan dzikir (ingat kepada Allah), maka dalam menghadapi permasalahan tersebut mereka akan menanggapinya dengan bijak dan tentunya hatinya juga akan tenang karena mereka berfikir bahwa mungkin Alah mempunyai kehendak lain dengan hal itu. Sebagaimana yang difirmankan Allah dalam surat ar-Ra'du/13 ayat 28,

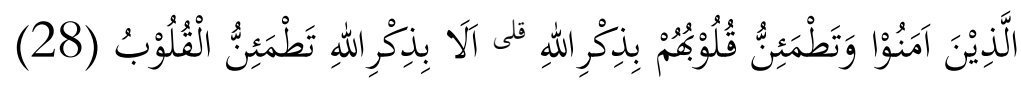

"(yaitu) orang-orang yang beriman dan hati mereka manjadi tenteram dengan mengingat Allah. Ingatlah, hanya dengan mengingati Allah-lah hati

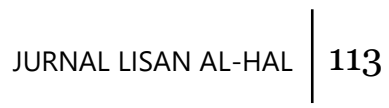


menjadi tenteram" [QS. Ar-Ra'du: 28]

Dijelaskan bahwa hati orang-orang mu'min akan menjadi tenang ketika mengingat Allah dikarenakan Allah melimpahkan cahaya iman kepadanya yang melenyapkan kegelisahan dan kesedihan. ${ }^{15}$ Ayat ini juga sesuai dengan firman Allah:

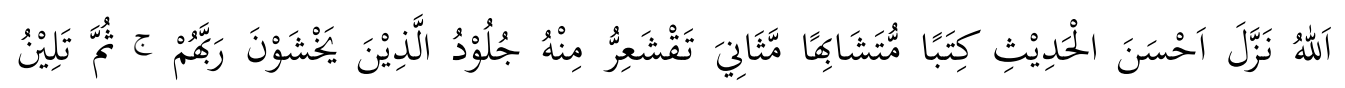

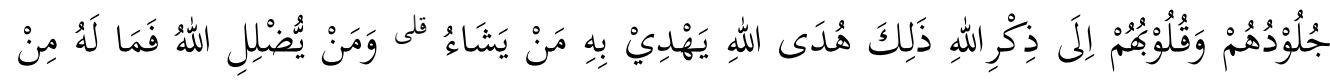

$$
\begin{aligned}
& \text { (23) }
\end{aligned}
$$

"Allah telah menurunkan Perkataan yang paling baik (yaitu) Al Quran yang serupa (mutu ayat-ayatnya) lagi berulang-ulang, gemetar karenanya kulit orang-orang yang takut kepada Tuhannya, kemudian menjadi tenang kulit dan hati mereka di waktu mengingat Allah. Itulah petunjuk Allah, dengan kitab itu Dia menunjuki siapa yang dikehendaki-Nya.dan Barangsiapa yang disesatkan Allah, niscaya tak ada baginya seorang pemimpinpun" [QS. AzZumar: 23]

\section{Baik dan Buruk}

Tentang sifat asal manusia yang hanya cenderung kepada kebaikan, ada dasarnya. Secara tekstual pernyataan ini sesuai dengan firman Allah SWT dalam surat At-Tīn/95 ayat 4,

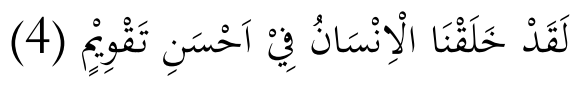

"Sesungguhnya Kami telah menciptakan manusia dalam bentuk yang sebaik-baiknya" [QS. At-Tin: 4]

Dari sini dapat disimpulkan bahwa yang fitrah, yaitu "apa yang menjadi bawaan manusia sejak lahir", dalam diri manusia hanyalah fitrah atau potensikebaikan. ${ }^{16}$ Sungguh pun manusia hanya memiliki sifat asal yang baik, ia tetap dapat berubah menjadi orang yang tersesat. Manusia "anak" diciptakan dalam keadaan baik, tetapi ketika tumbuh kembang ia dapat menjadi manusia yang sangat buruk. Sekalipun asalnya baik, namun manusia memiliki sifat fleksibel, suatu sifat yang diwarisi dari sifat yang melekat pada jasad manusia.Adanya fleksibilitas dalam diri manusia memungkinkan adanya pengaruh dari lingkungan eksternal manusia.

15 Ahmad Mustafa Al-Maragi, Tafsir Al-Maragi, terj. Anwar Rasyidi dan Al Humam, (Semarang: PT. Karya Toha Putra, 1994), 186.

${ }^{16}$ Sayyid Quthb, Tafsir fi Zhilalil-Qur'an, terj. As"ad Yasin dan Abdul Aziz Salim Basyarahil, (Depok: Gema Insani, 1992), 299.

114 JURNAL LISAN AL-HAL 
Hadirnya pengaruh buruk yang menimpa manusia pada gilirannya melahirkan sifat dan kebiasaan baru dalam jiwa manusia. Dengan sifat barunya yang telah diisi oleh pengaruh buruk dari lingkungan itu, manusia siap menyambut stimulasi-stimulasi dari lingkungannya.Daya tarik dari stimulasi buruk yang kuat akhirnya memungkinkan manusia melemah sifat asalnya yang positif dan terpengaruhlah oleh lingkungannya. Kuatnya stimulasi yang bersifat negatif akan menjadikan manusia salah urus. Dalam posisi yang jatuh, yang akhirnya menempati tempat yang paling buruk, manusia dipandang lebih buruk dari binatang, sebagaimana firman Allah dalam surat al-Furqan ayat 43-44 sebagai berikut:

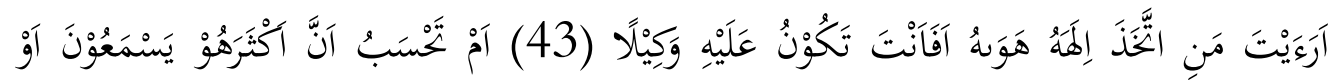

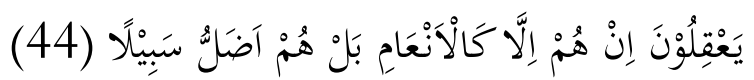

"Terangkanlah kepadaku tentang orang yang menjadikan hawa nafsunya sebagai Tuhannya. Maka Apakah kamu dapat menjadi pemelihara atasnya?.Atau Apakah kamu mengira bahwa kebanyakan mereka itu mendengar atau memahami.mereka itu tidak lain, hanyalah seperti binatang ternak, bahkan mereka lebih sesat jalannya (dari binatang ternak itu)" [QS. Al-Furqan: 43-44]

Dari sini dapat dikatakan bahwa manusia memiliki rentang kemungkinan yang sangat luas.Manusia dapat tumbuh menjadi makhluk yang sebaik-baiknya dan dapat pula tumbuh menjadi makhluk yang seburuk-buruknya. Dalam ungkapan lain, manusia dapat menjadi makhluk yang memilih jalanfujur"sesat". Ia bebas untuk menentukan sendiri apakah ia akan memilih untuk meneruskan pilihan-pilihan hidupnya atau tidak. Dalam situasi seperti ini,Al-Qur'an menggambarkan bahwa manusia memiliki kebebasan untuk memilih antara kebaikan dan keburukan.Ia bebas memilih menjadi orang yang bertaqwa atau orang yang fujur (menyimpang). Allah sendiri mengilhamkan kepada manusia untuk memilih jalan hidup yang lurus (selamat) atau jalan hidup yang menyimpang (tersesat), semua itu bisa dipahami oleh orang-orang yang mempunyai mata hati. ${ }^{17}$

Seperti yang dikatakan oleh Amin Syukur bahwa diantara manfaat dari dzikir adalah untuk menumbuhkan energi akhlaq yang baik.Dalam menghadapi kehidupan modern yang salah satu cirinya adalah ditandai dengan dekadensi moral, pendidikan Islam diharapkan mampu menjadi

${ }^{17}$ Ahmad Mustafa Al-Maragi, Op.Cit...,. 298.

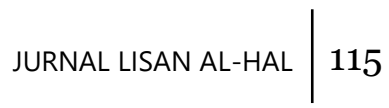


benteng untuk mengatasi permasalahan tersebut.Dalam keadaan yang seperti ini, sebagaimana yang telah disebutkan sebelumnya bahwa dzikir dapat menumbuhkan iman, dapat pula menjadi sumber akhlaq. Dengan demikian, dalam pendidikan Islam, khususnya bagi peserta didik harus selalu dibekali dengan dzikir (ingat kepada Allah) agar dalam mengarungi kehidupan ini tidak terjerumus ke dalam jurang kehancuran khususnya rusaknya moral yang mana nantinya tujuan dari pendidikan Islam tidak akan tercapai jika akhlak yang dimiliki oleh peserta didik mengalami kehancuran/kerusakan.

Selain itu manfaat lain yang dikatakan oleh Amin Syukur adalah dapat menghindarkan dari bahaya yang diakibatkan oleh adanya perbuatan buruk. Bagi peserta didik, bahaya itu bisa berasal dari dirinya sendiri maupun dari lingkungan sekitarnya. Dalam menghadapi hal semacam itu, peserta didik harus tetap ingat kepada Allah karena dengan cara ini mereka bisa mengendalikan diri serta sadar diri sehingga diharapkan dapat terhindar dari bahaya yang mengintainya atau pun dari bahaya yang timbul dari perbuatan buruknya.

\section{F. Simpulan}

Konsep dzikir menurut Amin Syukur dan relevansinya dengan tujuan pendidikan Islam itu mempunyai keterkaitan yang sangat erat. Dzikir merupakan cara untuk menjadikan seseorang menjadi manusia yang baik, berakhlaq mulia dan tentunya ingat akan penciptaannya di dunia ini yang bisa mengantarkan manusia menjadi insān kāmil. Karena dalam diri insān kāmil itu terintegrasi visi keimanan, keilmuan dan kemanusiaan dimana pembentukannya dibangun melalui proses pendidikan Islam. Insān Kāmil tanpa pendidikan Islam tidak akan bisa melakukan kaderisasi sehingga akan berakibat punahnya diri sendiri (mengalami kesenjangan bahkan hilangnya kader yang melangsungkan estafet perjuangan Insān Kāmil). Sebaliknya pendidikan Islam tanpa Insān Kāmil tidak akan mempunyai suatu sistem yang menjamin terlahirnya kader-kader pendidikan yang dapat berkiprah dalam kemajuan kehidupan dimasa mendatang. Sebagaimana tujuan dari pendidikan Islam adalah adalah merealisasikan ubudiyah kepada Allah di dalam kehidupan manusia agar dapat menemukan fungsi khalifah, baik dalam kehidupan individu maupun masyarakat untuk mencapai kebahagiaan dunia dan akhirat.

\section{DAFTAR PUSTAKA}

116 JURNAL LISAN AL-HAL 
Al-Ghazali. Mutiara Ihya Ulumuddin: Terj. Mukhatasar Ihya Ulumuddin, Bandung: Mizan. 2008.

Amin, Samsur Munir dan Al-Fandi, Haryanto.Energi Dzikir, tt.

Darajat, Zakiyah. Do'a Penunjang Semangat Hidup, Jakarta: CV Ruhama. 1994.

Dewan Redaksi Ensiklopedia Islam. Ensiklopedia Islam, Jakarta: PT. Ichtiar Baru van Hoeve. 2002.

Ilham, Muhammad Arifin. Menggapai Kenikmatan Dzikir. Depok: Intuisi Press. 2003.

Ilham, Muhammad Arifin. Menzikirkan Mata Hati: Pesan-pesan Spiritual Penjernih Hati, Depok: Intuisi Press. 2004.

Mustafa Al-Maragi, Ahmad. Tafsir Al-Maragi, terj. Anwar Rasyidi dan Al Humam, Semarang: PT. Karya Toha Putra. 1994.

Penerbit Toha Putra. Al-Qur'an dan Terjemahnya, Semarang: PT Toha Putra, tt.

Quthb, Sayyid. Tafsir fi Zhilalil-Qur'an, terj. As'ad Yasin dan Abdul Aziz Salim Basyarahil, Depok: Gema Insani. 1992.

Syukur, Amin dan Utsman, Fatimah. Insan Kamil "Paket Pelatihan Seni Menata Hati", Semarang: CV. Bima Sakti. 2006.

Syukur, Amin dan Utsman, Fatimah. Terapi Hati dalam Seni Menata Hati, Semarang, Pustaka Nuun. 2009.

Syukur, Amin. Dzikir Menyembuhkan Kankerku, Jakarta: Hikmah. 2008. 
"Konsep Dzikir Amin Syukur"

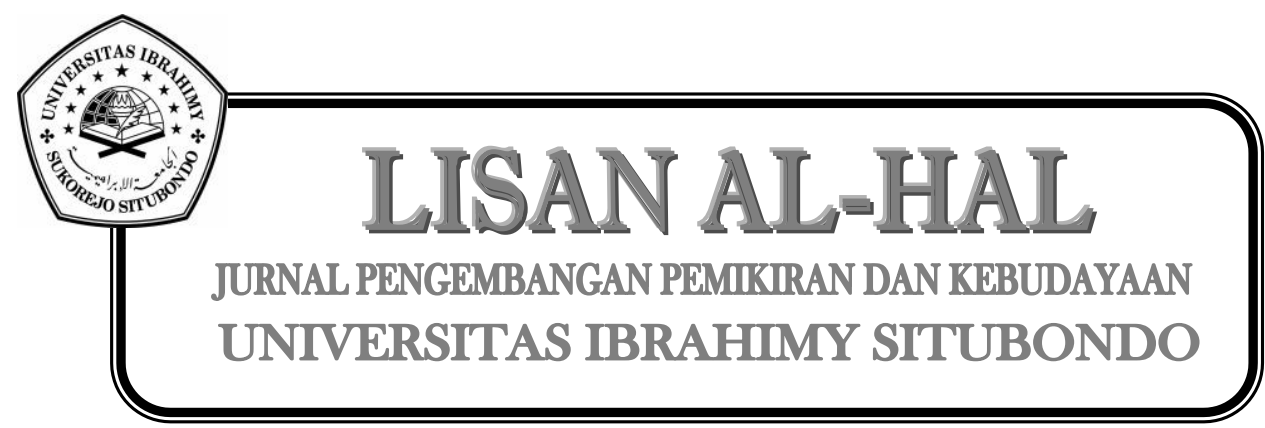

118 JURNAL LISAN AL-HAL 